\title{
Robert Deschaux, La Danse Macabre, dans Voix des mythes, science des civilisations. Hommage à Philippe Walter
}

\section{Maria Colombo Timelli}

\section{(2) OpenEdition}

\section{Journals}

\section{Édition électronique}

URL : http://journals.openedition.org/studifrancesi/375

DOI : $10.4000 /$ studifrancesi.375

ISSN : 2421-5856

\section{Éditeur}

Rosenberg \& Sellier

\section{Édition imprimée}

Date de publication : 1 avril 2015

Pagination : 132

ISSN : 0039-2944

\section{Référence électronique}

Maria Colombo Timelli, «Robert Deschaux, La Danse Macabre, dans Voix des mythes, science des civilisations. Hommage à Philippe Walter», Studi Francesi [En ligne], 175 (LIX | I) | 2015, mis en ligne le 01 avril 2015, consulté le 18 septembre 2020. URL : http://journals.openedition.org/studifrancesi/375 DOI : https://doi.org/10.4000/studifrancesi.375

Ce document a été généré automatiquement le 18 septembre 2020.

\section{c) $(9 \odot$}

Studi Francesi è distribuita con Licenza Creative Commons Attribuzione - Non commerciale - Non opere derivate 4.0 Internazionale. 


\title{
Robert Deschaux, La Danse Macabre, dans Voix des mythes, science des civilisations. Hommage à Philippe Walter
}

\author{
Maria Colombo Timelli
}

\section{RÉFÉRENCE}

ROBERT DESCHAUX, La Danse Macabre, dans Voix des mythes, science des civilisations. Hommage à Philippe Walter, Bern, Peter Lang, 2012, pp. 161-165.

Mythe des plus vivants à la fin du Moyen Âge, et dont la diffusion a été promue encore par les éditions imprimées, la Danse Macabre s'avère complexe tant par son mode d'expression, qui allie image, chorégraphie et texte, que par son interprétation. R.D. s'attache justement à l'ambiguïté du thème, qui associe estats du monde et inéluctabilité de la mort au motif d'une danse alternant squelettes souriantes et individus arrachés à leurs activités humaines: si la Danse Macabre peut être interprétée comme une invitation à se préparer à la mort, elle peut aussi se traduire en une incitation à profiter de la vie sur terre tant qu'il en est temps, voire en une acceptation de la hiérarchie sociale dans l'attente de l'au-delà. 